What the Problem of Evil Properly Entails

Neminemus

Author Note

neminemus@outlook.com 


\begin{abstract}
It is sometimes thought that the Problem of Evil entails the inexistence of God. However, this is not the case: it only entails the inexistence of an omnipotent-benevolent god, of which the God of Classical Theism is an example. As for 'limited' deities such as that of process theology, or malevolent deities such as that of dystheism, the problem of evil is not a problem at all.

Keywords: Problem of Evil; God; Christianity; Western Theology
\end{abstract}




\section{What the Problem of Evil Properly Entails}

OBSERVE THAT THE Logical Problem of Evil is one of the inconsistency of three premisses:

1. That there is an omnipotent god

2. That there is an omnibenevolent god

3. That there is evil and suffering

Hence it is said that

Evil is a problem, for the theist, in that a contradiction is involved in the fact of evil on the one hand and belief in the omnipotence and omniscience of God on the other. ${ }^{1}$

And that

Here it can be shown, not that religious beliefs lack rational support, but that they are positively irrational, that several parts of the essential theological doctrine are inconsistent with one another. ${ }^{2}$

If one so chooses, the various rectifications of this inconsistency can be placed on a spectrum, where there is on the one side total acceptance of the problem, that there is no god, so the first two premisses are false, which is atheism. An argument to this effect can be constructed thus:

1 If an omnibenevolent god exists, then evil does not

2 Evil exists

3 An omnibenevolent god does not exist

MT 1,2

${ }^{1}$ H. J. McCloskey, "God and Evil," page 97

2 J. L. Mackie, "Evil and Omnipotence," page 200. 
On the other side, there is total refutation of the problem, and that there is an omnipotentbenevolent god as well as evil, but the two are consistent, which is classical theism. And in between these two are partial acceptances, defences and theodicies, which deny one of the three premisses, which is theism, or deism, or pandeism or something of the sort, or offer morally sufficient reasons for the existence of evil, which is also classical theism.

Observe, then, that it is only the radical position of what we call total acceptance which maintains that the existence of evil and suffering entails that a god does not exist. Notice in David Hume's statement of the problem, that he does not consider any of the premisses to entail atheism:

Is he willing to prevent evil, but not able? then is he impotent. Is he able, but not willing? then is he malevolent. Is he both able and willing? whence then is evil? ${ }^{3}$

The atheistic position wants for external proof: were there a god proved, perhaps by the Cosmological Argument, or the Ontological Argument, we would not say of the proof that it is invalid on account of the Problem of Evil, but we would say of the god thus proved that it is either impotent or malevolent (or non-benevolent). And it is only if we should prove that there can be no such god that we can say of the Problem of Evil that it entails atheism. And of the aforementioned argument, its premisses entail the nonexistence of an omnibenevolent god, not the nonexistence of any and all gods.

As for the Evidential Problem of Evil, it is concerned with the good evidence for one of the positions badly favoured by classical theists: the rejection of a powerful god (process theology), the rejection of a loving one (dystheism), or the rejection of any god at all (atheism). Then, there

\footnotetext{
${ }^{3}$ David Hume, Dialogues Concerning Natural Religion, Part X.
} 
is, as well as the aforementioned matter, of what position is properly entailed by the soundness of the Problem of Evil, the additional matter, as to the soundness of the Evidential Problem of Evil.

We use the Evidential Problem of Evil because the logical one is generally considered rebutted by Alvin Plantinga's Free Will Defence, ${ }^{4}$ the logical is concerned with necessity rather than evidence i.e. likelihood, and because the evidential one is more robust. ${ }^{5}$

William Rowe is the most established proponent of the Evidential Problem of Evil. He presents his argument thus: ${ }^{6}$

1 There exist instances of intense suffering which an omnipotent, omniscient being could have prevented without thereby losing some greater good or permitting some evil equally bad or worse. could not do so without thereby losing some greater good or permitting some evil equally bad or worse.

There does not exist an omnipotent, omniscient, wholly good being.

The first premiss is called the factual premiss, the second the theological premiss. We will take the theological premiss as true, for it is consistent with the dogma and its theodicies. As for the factual premiss, it has two groups of evidence, because there are two types of evil: moral and natural. The former is evil that results from some man's going wrong with respect to an action that is morally significant for him; any other evil is natural evil. ${ }^{7} \mathrm{Mr}$. Rowe's evidence for natural evil is as follows:

\footnotetext{
${ }^{4}$ Alvin Plantinga, The Nature of Necessity, pages 166-167.

${ }^{5}$ The Oxford Dictionary of Philosophy s.v. "evil, problem of".

${ }^{6}$ William Rowe, "The Problem of Evil and Some Varieties of Atheism," page 336.

${ }^{7}$ Alvin Plantinga, op. cit. page 166.
} 
In some distant forest lightning strikes a dead tree, resulting in a forest fire. In the fire a fawn is trapped, horribly burned, and lies in terrible agony for several days before death relieves its suffering. ${ }^{8}$

It was natural evil of this kind that drove Charles Darwin away from classical theism after the death of his daughter. Hence we can call this variation of the problem the Darwinian Problem of Evil or the Problem of Predation.

I cannot persuade myself that a beneficent and omnipotent God would have designedly created the Ichneumonidæ with the express intention of their feeding within the living bodies of Caterpillars, or that a cat should play with mice. ${ }^{9}$

Mr. Rowe's evidence for moral evil draws from a real example, rather than the hypothetical instance of the fawn:

The girl's mother was living with her boyfriend, another man who was unemployed, her two children, and her 9-month old infant fathered by the boyfriend. On New Year's Eve all three adults were drinking at a bar near the woman's home. The boyfriend had been taking drugs and drinking heavily. He was asked to leave the bar at 8:00 p.m. After several reappearances he finally stayed away for good at about 9:30 p.m. The woman and the unemployed man remained at the bar until 2:00 a.m. at which time the woman went home and the man to a party at a neighbor's home. Perhaps out of jealousy, the boyfriend attacked the woman when she walked into the house. Her brother was there and broke up the fight by hitting the boyfriend who was passed out and slumped over a table when the brother left. Later the boyfriend attacked the woman again, and this time she knocked him unconscious. After checking the children, she went to bed. Later the woman's 5-year old girl went downstairs to go to the bathroom. The unemployed man returned from the party at 3:45 a.m. and found the 5-year old dead. She had been raped, severely beaten over most of her body and strangled to death by the boyfriend. ${ }^{10}$

One of the most obvious criticisms of the evidence for the Evidential Problem of Evil both moral and natural - is that, firstly, there is not enough of it: it is shocking precisely because it happens so infrequently. Secondly, it can be said that the majority of this evidence is of an insufficient calibre to warrant calling it evil.

${ }^{8}$ William Rowe, op. cit. page 337.

${ }^{9}$ Charles Darwin, letter to Asa Gray, 22 May 1860.

${ }^{10}$ William Rowe, "Evil and Theodicy," page 120. 
In response, observe that there is an additional type of evil which meets with both moral

and natural evil: horrendous evil. This is evil

\begin{abstract}
the participation in which (that is, the doing or suffering of which) constitutes prima facie reason to doubt whether the participant's life could (given their inclusion in it) be a great good to him/her on the whole... the rape of a woman and axing off of her arms, psycho-physical torture whose ultimate goal is the disintegration of personality, betrayal of one's deepest loyalties, child abuse of the sort described by Ivan Karamazov, ${ }^{11}$ child pornography, parental incest, slow death by starvation, the explosion of nuclear bombs over populated areas. ${ }^{12}$
\end{abstract}

Hence it should not be said that there is not evil of a sufficient calibre. And if it should be claimed that there is simply not enough horrendous evil to justify doubting the LORD, then observe that the history of the earth is in fact rife with it, including biblical history and the history of those who believe in an omnibenevolent god.

So it is that we must face a sobering fact: the history of our planet is a history stuffed with undeserved, horrific evil and suffering. ${ }^{13}$

Jesus Christ represented God as the principle of all good, the source of all happiness, the wise and benevolent Creator and Preserver of all living things. But the interpreters of his doctrines have confounded the good and the evil principle. ${ }^{14}$

I will cause it to rain upon the earth forty days and forty nights; and every living substance that I have made will I destroy from off the face of the earth. ${ }^{15}$

Then the Lord rained upon Sodom and upon Gomorrah brimstone and fire from the Lord out of heaven; and he overthrew those cities, and all the plain, and all the inhabitants of the cities, and that which grew upon the ground. ${ }^{16}$

And it came to pass, that at midnight the Lord smote all the firstborn in the land of Egypt, from the firstborn of Pharaoh that sat on his throne unto the firstborn of the captive that was in the dungeon; and all the firstborn of cattle. ${ }^{17}$

${ }^{11}$ Fyodor Dostoyevsky, The Brothers Karamazov, pages 284-285.

${ }^{12}$ Marilyn McCord Adams, Horrendous Evils and the Goodness of God, page 26.

${ }^{13}$ Daniel Howard-Snyder, "God, Evil and Suffering," page 78.

${ }^{14}$ Percy Bysshe Shelley, Essay on Christianity, pages 271-272.

${ }^{15}$ Genesis 7:4.

${ }^{16}$ Genesis 19:24-25.

${ }^{17}$ Exodus 12:29. 
What is more, the very principles ordering the world are innately violent. Evolution requires immense suffering before a specie evolves into a degree of safety. Growth is not possible without first experiencing some failure. The very will to life (wille zum leben) is driven by suffering: it manifests itself physically in nature which is 'red in tooth and claw'. ${ }^{18}$

\begin{abstract}
Thus everywhere in nature we see strife, conflict, and alternation of victory... The permanent matter must constantly change its form; for under the guidance of causality, mechanical, physical, chemical, and organic phenomena, eagerly striving to appear, wrest the matter from each other, for each desires to reveal its own Idea. This strife may be followed through the whole of nature; indeed nature exists only through it... This universal conflict becomes most distinctly visible in the animal kingdom. For animals have the whole of the vegetable kingdom for their food, and even within the animal kingdom every beast is the prey and the food of another; that is, the matter in which its Idea expresses itself must yield itself to the expression of another Idea, for each animal can only maintain its existence by the constant destruction of some other. Thus the will to live everywhere preys upon itself, and in different forms is its own nourishment, till finally the human race, because it subdues all the others, regards nature as a manufactory for its use. ${ }^{19}$
\end{abstract}

So it is without great difficulty that we can say that there is indeed good evidence for the conclusion of the Evidential Problem of Evil, that 'there does not exist an omnipotent, omniscient, wholly good being', which is why the theodical project is a difficult one.

But on accord of the first matter, as to what position this conclusion entails, we cannot say that there is any better evidence for the atheist position than there is for that of the process theist or the dystheist. Consider the Problem of Good, which maintains that there cannot be an evil god due to the presence of good in the world. We would not say that, because there cannot be an evil god, that there cannot be a god. It is clear that the problem is with the predicate i.e. goodness, and not with the god. So too from the Problem of Evil can it be said that there is good evidence that there is not an omnipotent-benevolent god, but not that there is good evidence that there is no god.

${ }^{18}$ Alfred Lord Tennyson, In Memoriam, Canto 56.

${ }^{19}$ Arthur Schopenhauer, The World as Will and Idea, Section 27. 


\section{Bibliography}

Adams, M. M. (1999). Horrendous Evils and the Goodness of God. Melbourne: Melbourne University Press.

Darwin, C. (1860). The Correspondence of Charles Darwin (Vol. VIII). (Burkhardt, F.; Browne, J.; Porter, D. M.; Richmond, M., Eds.) Cambridge: Cambridge University Press.

Dostoyevsky, F. (1912). The Brother Karamazov (Garnett, C., Trans.). New York: The Lowell Press.

Howard-Snyder, D. (1999). “God, Evil and Suffering.” In Murray, M. J. (Ed.), Reason for the Hope Within (pp. 76-115). Cambridge: William B. Eerdmans Publishing Company.

Hume, D. (1779). Dialogues Concerning Natural Religion. London.

Mackie, J. L. (1955). “Evil and Omnipotence.” Mind 64: 200-212.

McCloskey, H. J. (1960). “God and Evil.” Philosophical Quarterly 10: 97-114.

Plantinga, A. (1974). The Nature of Necessity. Oxford: Clarendon Press.

Rowe, W. L. (1979). "The Problem of Evil and Some Varieties of Atheism." American Philosophical Quarterly 16(4): 335-341.

—. (1988). "Evil and Theodicy." Philosophical Topics 16(2): 119-32.

Schopenhauer, A. (1883-1886). The World as Will and Idea. (Haldane, R. B.; Kemp, J., Trans.) London: Routledge \& Kegan Paul.

Shelly, P. B. (1875). Shelley Memorials: From Authentic Sources (3 ${ }^{\text {rd }}$ ed.). (Shelley, J. G., Ed.). London: Henry S. King \& Co.

Tennyson, A. (1850). In Memoriam. London: Edward Moxon. 